\title{
Ethical Reasoning in Capstone Students
}

Lynn Clark Callister

Brigham Young University - Provo

Patricia K. Ravert

Brigham Young University - Provo, patricia-ravert@byu.edu

Eva Stoneman

Brigham Young University - Provo

Geraldine Matsumura

Brigham Young University - Provo

Follow this and additional works at: https://scholarsarchive.byu.edu/facpub

Part of the Other Nursing Commons

\section{Original Publication Citation}

Callister, L.C.,Ravert, P., Stoneman, E., \& Matsumura, G. (2004). Ethical reasoning in capstone students. International Journal of Human Caring. 8(2), 54-60.

\section{BYU ScholarsArchive Citation}

Callister, Lynn Clark; Ravert, Patricia K.; Stoneman, Eva; and Matsumura, Geraldine, "Ethical Reasoning in Capstone Students" (2004). Faculty Publications. 5268.

https://scholarsarchive.byu.edu/facpub/5268 


\section{Ethical Reasoning in Capstone Students}

\section{Lynn Clark Callister, Ph.D., RN, FAAN, Patricia Ravert, Ph.D., RN, Eva Stoneman, RN, MS, and Geraldine Matsumura, Ph.D., APRN \\ Brigham Young University}

\begin{abstract}
Complex ethical issues characterize current healthcare environments. Nurse educators have been charged in the American Association of Colleges of Nursing (AACN) Essentials of Baccalaureate Education for Nursing Practice document with the responsibility to provide baccalaureate graduates with the knowledge and skills to apply ethical decision-making frameworks to clinical practice. However, there is a paucity of literature on ethical reasoning in nursing students. The purpose of this paper is to describe ethical reasoning in capstone students in an integrated baccalaureate nursing program. Themes identified from clinical journal entries include integration of ethics into both personal and professional life, strengthened commitment to professional integrity, and integration of the ethics of care with the ethics of justice. Helping students focus on empowered caring in nursing practice may be a significant way in which nurses can reform flawed healthcare delivery systems.
\end{abstract}

Key Words: Ethics, ethical reasoning, journals, baccalaureate education

Complex ethical issues characterize current healthcare environments. As part of interdisciplinary healthcare teams, nurses are challenged by ethical concerns in their clinical practice. Ethics includes "values, codes, and principles that govern decisions in nursing practice, conduct, and relationships" (American Association of Colleges of Nursing [AACN], 1998, p. 14). The characteristics of the ethical models that focus on either justice or caring are summarized in Table 1 (Botes, 2000). The literature was reviewed on ethics in nursing education and clinical nursing practice. The majority of studies reported in the literature focus on nurses in clinical practice rather than on ethical reasoning in nursing students just prior to graduation. The purpose of this paper is to describe ethical reasoning in capstone students in a baccalaureate nursing program.

\section{Literature Review}

\section{The Ethics of Caring in Clinical Nursing Practice}

There is a growing body of literature that focuses on the ethics of caring in clinical nursing practice. For 5 decades, the concept of "presence" is implicit and explicit in nursing theory (Covington, 2003). In both nursing education and nursing service, caring is a value expressed as overarching frameworks (Beck, 2001; Tuck, Harris, Renfro, \& Lexvold, 1998). In a metasynthesis of studies related to caring in nursing education, Beck concludes that "for nursing students to care for their patients, it is necessary for these students to experience

\section{Table 1}

Comparative Characteristics of Ethical Models

(Adapted from Botes, 2000)

\section{Fairness/equality}

Decision-making based on rules/ principles

Autonomy/objectivity/impartiality

Positivism
Empathetic caring/connectedness

Decisions based on context

Maintenance of harmonious interpersonal relationship

Holism caring in their educational environment" (p. 108) as faculty model caring practices such as presencing, sharing, and supporting. Tuck and associates suggest that caring in nursing service refers to "actions to assist, support, or facilitate another individual or group with evidence of anticipated needs to ameliorate or improve a human condition" (p. 92).

\section{Ethics in Clinical Nursing Practice}

In an overview of ethics in nursing practice, Cassidy (1996) summarized research with nurses in clinical practice as study participants. Moral sensitivity, moral judgement, moral reasoning, and situational experiences were measured. A correlational study examined the relationship between moral reasoning, coping styles, and stress related to ethical and moral issues in 229 oncology nurses (Raines, 2000).

\section{Ethics in Nursing Education}

The literature on ethics in nursing education is relatively sparse (Dinc \& Gorgulu, 2002; Hubert, 1999; Landry \& Landry, 2002; Nolan \& Markert, 2002; Rooda \& Nardi, 1999). Moral sensitivity in students and faculty, outcomes evaluation of ethical content in nursing education, assessment of the ability to make moral judgements, assessment of student moral intention, and integrity in academic behavior have been foci of research. A case study of a student nurse's perception of right and wrong has been described (Bosek, 1999). A longitudinal study was conducted in the United Kingdom that documented changes in ethical understanding over 4 years of nursing education. Students showed more uncertainty in their culminating course in nursing than at the beginning (Nolan \& Markert). Besides this work, no other studies were found that described ethical reasoning in nursing students just prior to graduation.

The Brigham Young University College of Nursing in the western United States has an integrated undergraduate curricular model. Essential curricular threads are inquiry, practice, stewardship, service, and 
Table 2

Ethical Knowledge and Skills in Baccalaureate Graduates*

Clarify personal and professional values and recognize their impact on decision-making and professional behavior.

Apply a professional nursing code of ethics and professional guidelines to clinical practice.

Apply an ethical decision-making framework to clinical situations that incorporates moral

concepts, professional ethics, and law and respects diverse values and beliefs.

Apply legal and ethical guidelines to advocate for patient well-being and preferences.

Apply communication, negotiation, and mediation skills to the ethical decision-making process.

Demonstrate accountability for one's own practice.

Take action to prevent or limit unsafe or unethical health and nursing care practices by others.

Enable individuals and families to make quality-of-life and end-of-life decisions and achieve a peaceful death.

* (American Association of Colleges of Nursing, 1998, p. 14)

spirituality. These threads are delineated on course maps, which document course content and learning activities, promote faculty and student accountability for learning outcomes, ensure logical consistency across nursing courses, and guide student learning experiences such as journaling (Callister, \& Hobbins, 2000; Conger, Baldwin, Abegglen, \& Callister, 1999). Because nurse educators have been charged with the responsibility to provide the baccalaureate graduate with the knowledge and skills summarized in Table 2, ethics content is found in all courses across the curriculum and is the primary focus of the nursing ethics course.

\section{Nursing Ethics Course}

The stewardship curricular thread is the specific emphasis in the nursing ethics course. In the ethics course, students are asked to submit journal entries that focus specifically on ethical dilemmas experienced during clinical practicum. Students addressed in their journal entries such issues as medication errors, inaccurate charting, failure to disclose complications to patients and families, end-of-life decisions, stereotypical attitudes toward patients, decisions about termination of pregnancy, administration of prn medication to manage patient behavior and decrease the workload of the nurse, child abuse and neglect, caring for high risk patients with potentially life threatening infectious diseases, and dealing with the chronically mentally ill and elderly with dementia.

The ethics course may be taken any time while the student is in the nursing program. In this course, students have the opportunity, individually and in small groups, to use clinical scenarios/case studies. This case study approach helps students form judgements about specific clinical situations that then are applied to other ethical dilemmas in clinical practice. The use of case studies in ethics courses is a widely used learning strategy (Hubert, 1999). Students also generate their own personal mission statements and are invited to apply that mission statement for several weeks and then articulate how that application is guiding their clinical practice. The Ethics Course Map is found in Table 3. The culminating capstone course "caps" the curriculum, including nursing ethics.

\section{Capstone Course}

The capstone course provides nursing students with their final opportunity for clinical synthesis experiences with a special focus on planning, delivering, and managing patient care in complex environments (Warnick, Callister, Tillery, Hammond, \& Mills, 1997). Evaluation of student learning includes journaling with an emphasis on the stewardship thread, which includes ethics. Students refine their personal mission statement that they developed during their ethics course and then "cap" their application of their mission statement in this culminating course.

\section{Ethical Reasoning in Capstone Students}

In assessing ethical reasoning in students approaching graduation, clinical journal entries were used with written permission from the student authors. Clinical journals provide a forum for the articulation of insights gained about ethical issues in practice. Journaling promotes student growth by articulating their core values and beliefs, and understanding the importance of incorporating those beliefs in their practice. Use of journaling provides a focus on critical reflective thinking rather than proscriptive duties and etiquette (Callister, 1993; Rooda \& Nardi, 1999). Such reflection helps students bridge the gap between the "ideal" and "real" worlds of clinical practice (Raines, 2000).

These journal entries cited are from capstone students in their last semester of their baccalaureate program who were either concurrently enrolled in an ethics course or who had previously completed the nursing ethics course. Providing students with the opportunity to share their own voices as they articulate the ethics of their fledgling nursing practice provides a context for understanding of self and the ethical milieu of healthcare delivery. The What? So What? and Now What? format is used to guide clinical journal entries.

What? The student gives a full description of an event and how it links to ethical practice. For example, one student described caring for an 85-year-old woman in severe congestive heart failure. She was on a ventilator with multiple intravenous lines sustaining her life. Her family told the staff they did not want extensive means taken and that medical interventions should be continued only if there was hope of recov- 


\section{Table 3}

Course Relationship to Curricular Threads (Nursing Ethics, Spring 2004)

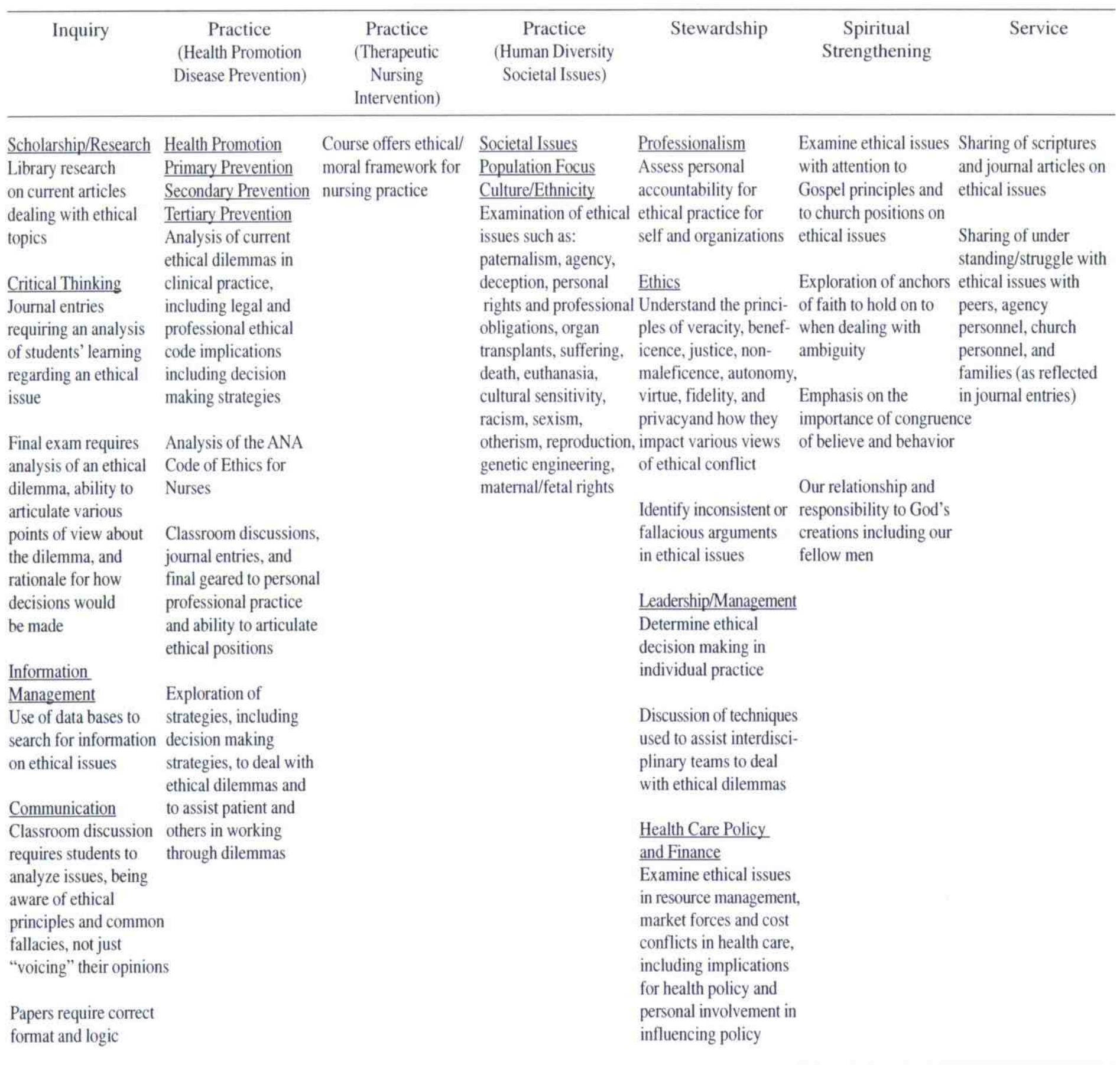

ery. In contrast, physicians continued to hold out hope for possible recovery and urged that interventions continue.

A second student wrote about the ethical dilemma of euthanasia while caring for a woman with Parkinson's disease who was in a vegetative state. Another student com- pared resuscitative efforts for a 5-month old with SIDS and an elderly woman who coded while being transported to the hospital. The student asked if aggressive efforts were equally appropriate in widely varying circumstances and wrote, "When we entered healthcare, we did not take upon us the right to play God."

So What? The student shares insights gained about ethical practice from the event including fallacious reasoning and ethical principles such as veracity and non-maleficence. For example, one student wrote about caring for a patient with HIV/AIDS 
who was ignored by the staff and not given the same quality of care as other patients. She concluded that the principles of justice and beneficence were violated.

A student who had been hospitalized for surgery wrote about her experiences from the "other side of the bed" as she became a recipient rather than a provider of care:

Although I never would have asked for this experience, I also would not trade it because of the lessons I learned and insights I gained. There is nothing like being a patient to gain a better understanding of patients. Through my experiences I learned that ethics is much more than just the "big decisions." It permeates all aspects of nursing care.

Now What? The student is asked to identify future implications for clinical practice. One student wrote, "Not only did I realize that there is more than one person that can be harmed but there are many ways to do harm. I will now consider the emotional, spiritual, mental, physical, and financial impact of healthcare decisions."

Another student who reflected on concerns about "drug seekers" in emergency departments concluded that:

In my practice, I will not allow myself to become like some of the distrustful nurses I have known, who withhold medication or administer it in inappropriate ways. I will keep an open mind, knowing that though it is my responsibility to give conscientious and appropriate care, it is also my responsibility to render quality care. I will examine each suspicious situation carefully and use caution in making assumptions based on "frequent flyer" status. It is my responsibility to give good nursing care and be an advocate for my clients. By adopting these standards as a part of my practice, I will be sure to give the best care I know how to give. Hopefully, my commitment to giving everyone appropriate benefit of the doubt will help me in my efforts to give quality care to patients in pain.
In future practice, I will treat these abusers of the emergency room with respect, no matter how difficult it is or how frustrated I become. I will set boundaries and not allow them to disrespect me. I will speak firmly to them but in a kind tone. I will not lose my temper. If necessary, I will step out of the room to regain my composure. I will utilize the tracking system with other hospitals in the area, members of the staff, and other appropriate resources to determine the amount and kind of interventions I use. I will utilize ethical decision-making and treat patients with the kind of respect I would like to receive.

Student journal entries were analyzed using guidelines for qualitative analysis. Trustworthiness of the data was ensured by having students review the conclusions of the faculty regarding their journal entries. Students wrote of lessons learned such as not judging before obtaining adequate information, not passing on negative judgements to other nurses, and the importance of responding appropriately when confronted with nurses who pass on negative comments or make inappropriate judgements about patients. As one student wrote, "I have the potential to have a positive effect on other nurses who may not realize the impact of their actions."

The following themes related to ethical reasoning in capstone students were identified through analysis of clinical journal entries.

1. Integration of ethics in both personal and professional life. One student wrote about the importance of "ethics in my practice everyday and in every way!" Students articulated a clear linkage between their personal selves and their professional selves. A student described a situation in which a 30-year-old male was seen in the emergency department for drug overdose in a suicide attempt following the death of his father. $\mathrm{He}$ was dirty, unkempt, and constantly muttering obscenities. The student said:

The nurses working with him were unwilling to show him kindness. They acted so disgusted. I couldn't help but feel despair for the way this man was being cared for. In my student manner, awkward and unsure, I attempted to show him love. I could see that he needed a sense of caring to connect with during this painful time of life and during painful procedures. It was a simple effort to fill a need I felt was crucial to the patient. It is my conviction, after having this experience, to show kindness, gentleness, and love to every patient regardless of lifestyle differences. What if this man were my brother? How would he be treated differently? Caring is who we are. It embodies our character. Working as a student on labor and delivery has really opened my eyes to the accountability issues that are involved in giving care to childbearing women and their families. One has to make moral decisions according to their own ethical standards and in agreement with the laws that dictate nursing care.

\section{Strengthened commitment to profes-} sional integrity. A student wrote about heart rending experiences in the Newborn Intensive Care Unit (NICU) focusing on issues such as quality and quantity of life and the tension between greater good for one very low birth weight infant versus using economic resources for the greatest number. The student had looked at these issues previously in a neurological clinical nursing course where she cared for cognitively impaired patients with severe head injuries and committed herself to careful and thoughtful consideration of all facets of ethical decision-making.

One student wrote about assisting in surgery with a breast biopsy and the performance of a radical mastectomy while the woman was still under anesthesia, leaving a life-altering decision to her caregivers by giving "blanket" consent. The student asked, "Was the doctor's decision one of beneficence or rather one of efficiency?"

A student worked with the charge nurse on a surgical floor. Hispanics patients who 
spoke no English were assigned to nurses who spoke no Spanish. She raised the issue of whether or not informed consent had really been obtained. She wrote, "Human diversity necessitates nurses be aware of the special needs of diverse people. Every person is unique and deserves to have their uniqueness recognized and respected." Another student wrote of caring for a 16 year old in congestive heart failure, 2 years post heart transplant. Errors were made in her care, including administration of CMV+ packed red blood cells despite her compromised immune status. Neither the mother nor the patient was told of the error and the patient subsequently died. The student wrote:

The patient and her mother should have been told about that mistake and others that were made in her treatment. This experience gave me a new appreciation for life and for the difference a nurse can make in a person's life.

Nursing takes experience, time, and a willingness to push yourself above and beyond what you think is expected of you. I have a long way to go but I hope I am heading in the right direction.

Noting lavish "perks" for administrative personnel in meetings grappling with salary issues for staff nurses, one student concluded:

If $\mathrm{I}$ ever become an administrator in a corporation, I will remember the staff that makes the corporation before I allocate resources to those who govern the corporation. I will work to give people the respect they deserve, even if it means only saying "thank you" and "I appreciate you." Hopefully, I will be aware of what will do the greatest good to the greatest number of people, instead of what would do me the greatest good.

\section{Integration of the ethics of care with} the ethics of justice. Empowered caring was the predominant theme of student journal entries. The ethics of justice or principled thinking is dominant in medical ethics. In contrast, the ethics of care focuses on caring as a major perspective for resolving ethical dilemmas (Botes, 2000). Student journal entries demonstrate commitment to empowered caring. This supports the themes in Wurzbach's (1999) qualitative study of moral certainty, which included speaking up, taking a stand, and refusing to participate. One student articulated her perspectives in this way after caring for a critically ill boy with end stage cystic fibrosis whose family was having difficulty letting go:

I have realized that I need to reserve judgments of an absolute nature. What is right at one time and place for a certain person is not necessarily right down the road or for a different person. Reserving judgment, along with having a knowledge base, leads us to make the wisest decisions. Decisions about life and death cannot be rushed. They ought to be meditated upon, looked at from every angle, and only after serious consideration of every option should a decision be made. The surest principle of correct decision-making is if one feels peace about a well-thought through decision.

After clinical experiences in critical care units, the following commitments were made:

I commit to provide the same quality care for the patient who has every hope of recovery and the patient who will most likely die. I commit to be honest with families within my realm of practice. I commit never to mislead or give false hope that will cause additional suffering to a patient entrusted to my care. I commit to educate patients about the importance of advanced directives.

Speaking of overwhelming global health issues after being part of humanitarian healthcare team in Vietnam, the student said: As a nurse I felt very small. I was only one person. What could I do to meet the crying needs of the suffering around the world? I think sometimes what is easily forgotten is the incomprehensible impact we can have on others. Someone eloquently said, "What you say and do will carry hope and give direction to people far beyond your natural abilities and your own understanding." I need to understand that the potential I have to lift others is far greater than I think. One of my goals is to go back to my home in Asia and be a nurse there.

Another student wrote about being confronted with a man who was HIV positive in the emergency department who had an open wound:

In the few seconds that I had available to me I did some deep soul searching about what I stand for and who I believe should have access to healthcare and I cleaned the wound. I only hope that my few seconds of indecision and fright did not show on my face. This moment was life changing for me as a nurse because I realized that I have the capacity to care for and love people even when they have a disease that could harm me. I hope I never hesitate again.

A student caring for a young Hispanic couple who had experienced fetal demise spoke of efforts made in her halting Spanish to demonstrate the empathy she felt for their circumstances in the loss of a much loved and wanted child:

I took the mother's hand and said,

"Entiendo que se ha mierto el bebe (I understand your baby has died)." I didn't know if it was the right thing to say but I just couldn't pretend away the truth. I had to acknowledge that this event was real. I also said, "No se muchas palabras, pero tengo mucha tristeza para usted (I don't know many words but I have a lot of sadness for you)." Initially, she had looked away from me with her eyes full of tears. But then she looked at me, squeezed my hand in return, and said, "Thank you." Analysis of clinical journal entries of capstone students identified themes including integration of ethical content both personally and professionally, a strong commitment to professional integrity, and the integration of the ethics of caring with the ethics of justice. Students completing their baccalaureate education were commit-

\section{International Journal for Human Caring}


ted to empowered caring. Having the opportunity to reflect on their experiences of growth toward the ethics of caring offered what Covington (2003) has described as a "space for sharing significant emotions as both [student] nurse and patient grow and heal along life's journey" (p. 316). In addition to journal entries documenting this commitment to caring, Covington has beautifully expressed the importance of "being there to share another's experience," described as the "therapeutic process of sharing between nurse and client during an experience of illness and suffering." The importance of this philosophical basis for clinical nursing practice is supported in the literature, as Kendrick and Robinson (2002) have also explicated the importance of relationship ethics in nursing practice.

\section{Implications for Nursing Research and Nursing Education}

As a result of this analysis of ethical reasoning in capstone students, the following suggestions are made for inquiry:

1. Use of qualitative methods in investigating the moral competency of nursing students (Streubert \& Carpenter, 1999). For example, replication of Wurzbach's (1999) study of acute care nurses and moral certainty with nursing students as study participants would be of value.

2. Use of the Nursing Professional Values Scale (Weis \& Schank, 2000) as a preintervention screening instrument and a post-intervention evaluation tool as an outcomes measure following completion of a bioethics and/or culminating capstone course. One caution is that measurement of professional values is very complex requiring use of more than one instrument and perhaps the triangulation of qualitative and quantitative data.

3. Prospective longitudinal studies measuring how the processes of insights and abilities change over time evaluating moral judgment, reasoning, and sensitivity in new graduates, at 1 year and 5 years of clinical nursing practices. The tool developed by Nolan and Markert
(2002) may prove useful.

Gaining an understanding of the ethical reasoning of nursing students in their culminating course will help faculty generate learning experiences for future students, which will facilitate entry into the complex world of professional nursing practice in a changing healthcare delivery system. A study conducted at a Turkish university evaluated nursing ethics content in the curriculum (Dinc \& Gorgulu, 2002). Such ongoing outcomes evaluation of ethical content is imperative.

Taylor (2000) has identified some strategies that may be helpful to faculty in enhancing students' ability to manage ambiguities that may occur in clinical settings through the use of case studies. It has been concluded that "current educational processes are not sufficient to elevate the sensitivity of students to the level needed to address the diversity of ethical issues in practice" (p. 174). The AACN Essentials document (1998), ANA, and ICN Code of Ethics should guide ethical curricular development.

In a "life skills" outcomes focused framework at the University of Louisville School of Nursing, an important outcome is for graduates to "demonstrate personal and professional life skills and commitment to lifelong learning and service to the profession and community" (Freeman, Voignier, \& Scott, 2002, p. 38). The National Bio-Ethics Library at the Kennedy Institute of Ethics, Georgetown University, Washington, DC, has a collection of sample ethics curricula for nursing students that may prove useful in curricular development. The toll-free number is (800) 633-3849.

Guidelines should be generated for ethics content at different educational levels (Ketefian, 1999). Helping students focus on empowered caring as integral to their nursing practice may be a significant way in which nurses can reform flawed healthcare delivery systems (Rankin, 2000). As one student wrote about the commitment to the ethics of caring, "I would simply like to be known as a patient advocate and a nurse with integrity."

\section{References}

American Association of Colleges of Nursing. (1998). Essentials of baccalaureate education for nursing practice. Washington, DC: Author.

American Nurses Association. (2001). The American Nurses Association code of ethics for nurses. Washington, DC: Author.

Beck, C.T. (2001). Caring within nursing education: A metasynthesis. Journal of Nursing Education, 40(3), 101-109.

Bosek, M.S.D. (1999). Ethics in practice: A student nurse's perception of right and wrong. Journal of Nursing Administration's Healthcare Law, Ethics, and Regulation, I(3), 16-19.

Botes, A. (2000). A comparison between the ethics of justice and the ethics of care. Journal of Advanced Nursing, 32(5), 1071-1075.

Callister, L.C., \& Hobbins, D. (2000). "Enter to learn, go forth to serve": Service learning in nursing. Journal of Professional Nursing, 16(3), 177-183.

Callister, L.C. (1993). The use of student journals in nursing education: Making meaning out of clinical experience. Journal of Nursing Education, 16(3), 177-183.

Cassidy, V.R. (1996). Moral competency. In J.J. Fitzpatrick \& J. Norbeck (Eds.), Annual Review of Nursing Research, 14 , 181-204. New York: Springer.

Conger, C.O., Baldwin, J.H., Abegglen, J., \& Callister, L.C. (1999). The shifting sands of health care delivery: Curriculum revision and integration of community health nursing. Journal of Nursing Education, 38(7), 304-311.

Covington, H. (2003). Caring presence. Journal of Holistic Nursing, 2l(3), 310-317.

Dinc, L., \& Gorgulu, R.S. (2002). Teaching ethics in nursing. Nursing Ethics, 9(3), 259-268.

Freeman, L.H., Voignier, R.R., \& Scott, D.L. (2002). New curriculum for a new century: Beyond re-packaging. Journal 
of Nursing Education, 4I(1), 38-40.

Hubert, J. (1999). The thought experiment as a pedagogical device in nursing ethics education. Journal of Nursing Education, 38(8), 374-376.

International Council of Nurses. The International Council of Nurses code of ethics for nurses. Retrieved from http://icn/ch/icncode.pdf

Kendrick, K.D., \& Robinson, S. (2002).

"Tender loving care" as a relational ethic in nursing practice. Nursing Ethics, 9(3), 291-300

Ketefian, S. (1999). Ethics content in nursing education. Journal of Professional Nursing, 15(3), 138.

Landry, H., \& Landry, M. (2002). Nursing ethics and legal issues: An integrative approach in nursing education. Journal of Nursing Education, 4I(8), 363-364.

Nolan, P.W., \& Markert, D. (2002). Ethical reasoning observed: A longitudinal study of nursing students. Nursing Ethics, 9(3), 243-258.

Raines, M.L. (2000). Ethical decision making in nurses: Relationships among moral reasoning, coping style, and ethics stress. Journal of the Organization of Nurse Administrators, 2(1), 29-41.

Rankin, W.W. (2000). Ethics of care and empowerment of nurses. Journal of Pediatric Nursing, 15(3), 193-194.

Rooda, L.A., \& Nardi, D.A. (1999). A curriculum self study of writing assignments and reflective practice in nursing education. Journal of Nursing, 38(7), 333-335.

Streubert, H.J., \& Carpenter, D.R. (1999). Qualitative research in nursing:

Advancing the humanistic imperative.
Philadelphia: Lippincott.

Taylor, P.A. (2000). Strategies for enhancing student learning by managing ambiguities in clinical settings. Nurse Educator, 25(4), 173-174.

Tuck, I., Harris, L., Renfro, T., \& Lexvold, L. (1998). Care: A value expressed in philosophies of nursing services. Journal of Professional Nursing, 14(2), 92-96.

Warnick, M., Callister, L.C., Tillery, C., Hammond, K., \& Mills, D. (1997).

Capstone: An outcome focused curricular response to the changing environment. Proceedings: Western Institute of Nursing Assembly Communicating Nursing Research, pp. 67-72.

Weis, I., \& Schank, M.J. (2000). Instrument to measure professional nursing values. Journal of Nursing Scholarship, 32(2), 201-204.

Wurzbach, M.E. (1999). Acute care nurses' experiences of moral certainty. Journal of Advanced Nursing, 30(2), 287-293.

\section{Author Note}

Lynn Clark Callister, Patricia Ravert, Eva Stoneman, and Geraldine Matsumura, College of Nursing, Brigham Young University, Provo, Utah.

Appreciation is expressed to the nursing students who shared their clinical journal entries.

Correspondence concerning this article should be addressed to Lynn Clark Callister, 136 Kimball Tower, Brigham Young University, Provo, Utah 84602-5544 USA. Electronic mail may be sent via Internet to lynn_callister@byu.edu

\section{International Journal for Human Caring}


Copyright of International Journal for Human Caring is the property of International Association for Human Caring and its content may not be copied or emailed to multiple sites or posted to a listserv without the copyright holder's express written permission. However, users may print, download, or email articles for individual use. 